\title{
ATELIÊ DIGITAL INTEGRADO: SEGUNDO ANO DA EXPERIÊNCIA DE ENSINO DE /PROJETO ARQUITETÔNICO MEDIADO POR COMPUTADOR
}

Digital Integrated Ateliê: second year of computer-mediated architectural design teaching experience

\section{Sergio Dias Maciel ${ }^{1,2}$, Arivaldo Leão de Amorim², Érica de Sousa Checcucci ${ }^{2}$, Kyane Bomfim Santos}

RESUMO: Esse artigo apresenta e discute os resultados alcançados no ano 2017 por alunos do Curso de Graduação em Arquitetura e Urbanismo da Universidade Federal da Bahia, nas disciplinas Ateliê I (com alunos ingressantes) e Ateliê II (com alunos de segundo ano), que foram ministradas simultaneamente, compondo a disciplina Ateliê Digital Integrado. Esta atividade é desdobramento do Ateliê Digital (ARQ 016), realizado em 2016, quando foi ofertada a primeira turma desta disciplina para alunos de primeiro ano do curso tendo sido obtidos resultados muito significativos. A proposta pedagógica desenvolvida partiu do pressuposto que o ensino da projetação arquitetônica em ambiente digital pode ser vantajoso desde as séries iniciais, e nesse caso, a oferta das duas turmas de Ateliê Digital (2016 e 2017) adotou a ampla utilização do computador como principal recurso para as pesquisas, desenvolvimento das atividades e a apresentação dos projetos. A metodologia de ensino-aprendizagem ativa buscou estimular o desenvolvimento da criatividade e a independência nos estudantes. Como resultado, foi verificado que o uso do computador potencializou a projetação, fazendo com que houvesse um tempo maior dedicado à discussão sobre a solução do problema arquitetônico, favorecendo o ensino e a aprendizagem. Ao final do Ateliê Digital Integrado (2017), os alunos demonstraram amadurecimento e autonomia na projetação, com propostas bem fundamentadas e bem desenvolvidas. O nível de desenvolvimento dos exercícios projetuais e a representação técnica foi compatível com as exigências do Ateliê I (estudo preliminar) e do Ateliê II (anteprojeto), sem quaisquer prejuízos à exploração da forma ou da criatividade. Este artigo apresenta os resultados, bem como questões relacionadas à operacionalização da atividade, integrando turmas de anos diferentes; discute algumas dificuldades encontradas no processo e como foram superadas, dentre outros aspectos. Com a discussão sobre esta prática inovadora e bem-sucedida, espera-se contribuir para acelerar a adoção de ferramentas computacionais no ensino de projeto em cursos de graduação em Arquitetura e Urbanismo.

PALAVRAS-CHAVE: Ensino de projeto; Ensino de projeto em ambiente digital; Projeto de arquitetura; CAAD; Modelagem geométrica; Metodologia ativa de ensino-aprendizagem.

ABSTRACT: This article presents and discusses the results achieved in 2017 by students of the undergraduate course in Architecture and Urbanism at Federal University of Bahia, in the subjects Ateliê I (with new students) and Ateliê II (with second year students), which were taught simultaneously, composing the Digital Integrated Ateliê. This activity is an offshoot of Ateliê Digital (ARQ 016), held in 2016, when the first class was offered to first year students of the course, with very significant results. The pedagogical proposal developed was based on the assumption that the teaching of architectural design in a digital environment can be advantageous from the early grades, and in this case, the creation of the two Digital Atelier classes (2016 and 2017) adopted the wide use of the computer as the main resource for research, development of activities and presentation of projects. The active teaching-learning methodology sought to stimulate the development of creativity and independence in students. As a result, it was found that the use of the computer potentiated the design, leading to a longer time dedicated to the discussion about the solution of the architectural problem, favoring teaching and learning. At the end of the Digital Integrated Ateliê (2017), students demonstrated maturity and autonomy in design, with well-founded and well-developed proposals. The level of development of the project proposals and the technical representation was compatible with the requirements of Ateliê I (preliminary study) and Ateliê II (preliminary project), without any prejudice to the exploitation of form or creativity. This article presents issues related to the operationalization of the activity, integrating classes from different years, discusses some difficulties encountered in the process and how they were overcome, among other aspects. By discussing this innovative and successful practice, it is expected to contribute to accelerate the adoption of computational tools in project teaching in undergraduate courses in Architecture and Urbanism.

KEYWORDS: Projection teaching; Teaching project in digital environmental; Architectural design; CAAD; Geometric modeling; Active teaching-learning methodology.

\section{How to cite this article:}

MACIEL, S. D.; AMORIM, A. L.; CHECCUCCI, É. S.: SANTOS, K. B. Ateliê digital integrado: segundo ano da experiência de ensino de projeto arquitetônico mediado por computador. Gestão e Tecnologia de Projetos, São Carlos, v.16, n.1, p.60-79, jan.2021. http://dx.doi.org/10.116/gtp.v16i1.163235

Fonte de financiamento: Conflito de interesse:

Submetido em: 14 ra nao have

Submetido e

Aceito em:

[Disponivel online em Dezembro de 2020 


\section{INTRODUÇÃO}

O ensino da projetação arquitetônica mediada por computador, se conduzido adequadamente, pode potencializar o processo de ensino-aprendizagem de alunos desde as primeiras séries do curso de Graduação em Arquitetura e Urbanismo. Adotando-se recursos digitais na projetação, ainda na etapa de fundamentação, na realização de pesquisas iniciais e na busca por projetos de referências, passando pelo apoio na concepção e no desenvolvimento das propostas, é possível destinar um maior tempo do curso para que professores e alunos possam discutir mais sobre a arquitetura e a prática projetual, uma vez que se pode racionalizar e otimizar questões referentes a representação arquitetônica e outras rotinas de projeto.

Com o objetivo de aprofundar a discussão que envolve o ensino e a aprendizagem do projeto arquitetônico em ambiente digital na graduação em Arquitetura e Urbanismo, foram realizadas duas turmas, denominadas de Ateliê Digital, na Universidade Federal da Bahia, com o amplo emprego de recursos digitais, conforme apresentado em Maciel (2019).

A primeira turma foi realizada em 2016 na disciplina ARQ016 - Ateliê I, com alunos do primeiro ano do curso, cujo rendimento foi considerado altamente positivo pelos professores envolvidos e foi discutida em artigo publicado na Revista Gestão e Tecnologia de Projetos (MACIEL, AMORIM, CHECCUCCI, 2018). O resultado obtido em 2016 motivou em 2017, a oferta da segunda turma, constituída pelas disciplinas ARQ016 - Ateliê I (novos alunos ingressantes) e ARQ024 - Ateliê II (alunos de segundo ano que haviam cursado o Ateliê Digital em 2016). Além de aprimorar os métodos de ensino e aprendizagem propostos no ano anterior, em 2017 adicionou-se o desafio de trabalhar com duas disciplinas de forma integrada, com alunos de dois anos diferentes. Este artigo enfoca, apresenta e discute esta segunda abordagem.

\section{A Projetação arquitetônica e o ensino}

As atividades de projetação arquitetônica costumam seguir rotinas tradicionais que envolvem a discussão sobre o problema arquitetônico, a pesquisa envolvendo o tema e as restrições, os aspectos legais, técnicos e de recursos conforme Silva (1998) e Lawson (2010). Também são comuns as abordagens ao projeto segundo métodos heurísticos descritos por Broadbent (1973) e Rowe (1991), os mundos projetuais de Mitchell (2010) e estudos de composição descritos por Mahfuz (1995).

Durante a projetação, objetiva-se como síntese para o problema arquitetônico a construção do partido arquitetônico, conforme Silva (1998) e Neves (1998), a partir da definição do programa de necessidades, prédimensionamento, estudo de relações funcionais (funcionogramas) e dos diversos fluxos utilizando-se de diagramas.

Na avaliação do partido arquitetônico e do seu refinamento nas etapas subsequentes, são levados em consideração a qualidade arquitetônica, que segundo Voordt e Wegen (2013), diz respeito a qualidades espaciais como coerência na elaboração da forma, a integração entre o interior e o exterior, a legibilidade na elaboração dos espaços, a estrutura na adoção do partido e a compatibilidade do sistema construtivo. Mahfuz (2003) também destaca a importância do lugar e sua interrelação com o projeto e sua construção.

Para Mahfuz (2003) e Malard (2005) o aprendizado da projetação arquitetônica ocorre por meio da prática projetual, desenvolvida em disciplinas curriculares (chamadas de ateliê, por exemplo) cujo objetivo é resolver problemas projetuais propostos ao longo do curso. As soluções dos alunos retornam aos professores para a verificação e validação da solução, segundo a reflexão crítica e experiência de cada professor.É pelo acúmulo de informações e experiências adquiridas na projetação, quando são realizadas pesquisas, experimentações e argumentações que ocorre a transmissão do conhecimento arquitetônico. 
Schon (2000) descreve que os ateliês, individuais ou coletivos, são similares à prática profissional, que possuem rituais próprios em um processo de "aprender através do fazer", destacando-se as figuras do instrutor e aluno como agentes do que descreve como "ensino prático

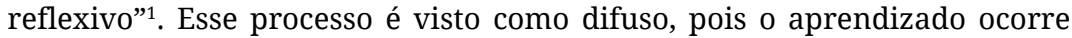
no relacionamento entre os participantes, de modo inconsciente a partir de novos raciocínios e estratégias de ação. Cada nova experiência traz reflexões ao aluno num processo de criação de um repertório próprio. Esse processo de modo contínuo, possibilita novas experiências enriquecendo o aluno.

Para Malard (2018), a projetação deve conectar ideias, teorias e inspirações para serem arregimentados em uma solução, por meio de uma análise crítica. Fazem parte dos exercícios de projetação, grupos distintos de conhecimentos, sendo estes os fundamentos técnicos, os fundamentos filosóficos, teóricos e metodológicos; e a instrumentação, que articulados conjuntamente subsidiam a síntese arquitetônica, como uma das partes que compõem a projetação.

Com relação ao ensino/aprendizagem, Janot (2003) e Vargas (2005) apontam para uma possibilidade de inversão do foco em sala de aula, ou seja, em vez de privilegiar o conhecimento do professor, o ensino deve centrar-se no aluno e em suas habilidades, com diferentes metodologias aprimorando o processo educativo. Neste caso, o professor, assume um papel de mediador do conhecimento devendo estimular a autonomia dos alunos nas atividades de projetação, na busca pela melhor resolução dos problemas propostos e incentivando-os a identificar e combinar diferentes ferramentas e recursos. As transformações que são exigidas como novas metodologias de ensino fazem parte da metodologia ativa.

Com relação a metodologia ativa, Moran (2013) diz que a aprendizagem ocorre em três movimentos distintos, o individual com o aluno em seu percurso; em grupo, com as relações entre seus semelhantes; e o orientado, com o auxílio dos mais experientes. No processo de ensino/aprendizagem, os alunos devem ser incentivados a serem os produtores de conhecimento e não somente receptores, sendo o compartilhamento do conhecimento fundamental, devido à complexidade e a dinamicidade dos ambientes sociais. Afirma ainda que, nos casos em que há a necessidade da transformação no ensino e no papel de seus participantes, a tecnologia facilita a aproximação e a colaboração entre todos (MORAN, 2013).

Para Camargo e Daros (2018), é necessário que o aluno tenha condições de transitar entre as diferentes formas de ensino com autonomia e destacam importantes abordagens como as discussões em grupo, a prática do conhecimento e o ensino ao outro. Dessa forma, tem sido recorrente, tentativas de mudanças ou de enriquecimento no processo de ensino da projetação arquitetônica, não apenas com relação a utilização da instrumentação e de novos recursos digitais, mas na articulação dos agentes participantes do processo de ensino/aprendizagem.

Barison (2015) destaca diferentes formas de constituir grupos para desenvolvimentos de projetos ${ }^{2}$, como o Ateliê de Projetos Interníveis (reunindo alunos de cursos diferentes e em diferentes níveis) e Ateliê de Projeto Transdisciplinar (com a inclusão de disciplinas e alunos de cursos distintos), ambos realizados na Virginia Polythecnic Institute and State University. No Brasil, Batistello e colaboradores (2016) destacam a utilização do Ateliê Vertical (alunos de diferentes níveis de um mesmo curso) atuando em maratonas de projeto.

Dentro deste quadro de mudanças, Nardelli (2007) diz que há a necessidade do rompimento nos paradigmas do trabalho e do ensino de arquitetura, que envolvem a utilização do computador de modo limitado, como substituição dos recursos tradicionais. É necessário reorganizar novas formas de ensinar e aprender, otimizando a projetação, em metodologias próprias para a utilização dos recursos digitais, uma vez que o domínio da tecnologia não se sobrepõe ao desenho manual, mas o complementa.

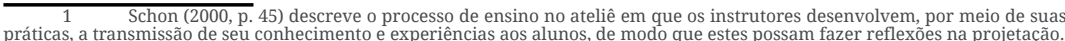

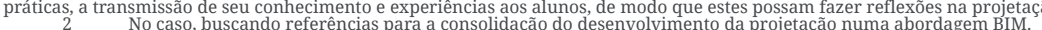


Para Kowaltowski e colaboradores (2006), o uso do computador pode significar outra forma de prazer na representação, adquirido pelo corpo discente atual que está amplamente adaptado à tecnologia. Dessa forma, a projetação arquitetônica através da construção de modelos geométricos das edificações, traz como uma de suas vantagens uma melhor compreensão da solução arquitetônica, amplamente discutido na literatura por Andrade (2007), Florio (2007; 2012) e Kim (2012).

Assim, o ensino da projetação arquitetônica precisa desenvolver várias formas de interação entre os participantes e os recursos para estar alinhado às necessidades contemporâneas. É preciso que as ferramentas digitais sejam acrescidas às metodologias projetuais e aos conhecimentos arquitetônicos necessários, de modo a dinamizar as ações e a comunicação entre os participantes do processo: alunos e professores. Diante disto, este trabalho apresenta e discute uma experiência realizada com estes princípios.

\section{A METODOLOGIA UTILIZADA NO ATELIÊ DIGITAL INTEGRADO}

Na FAUFBA ${ }^{3}$, as disciplinas de projeto arquitetônico são anuais, e cada uma possui carga horária de 12 horas semanais. Tanto as turmas de Ateliê I quanto Ateliê II normalmente possuem 15 alunos cada e são ministradas agrupadas em turmas de 30 alunos sob responsabilidade de dois docentes a cada ano. No caso do Ateliê Digital Integrado, agrupou-se uma turma de Ateliê I com outra de Ateliê II. A disciplina foi conduzida conjuntamente pelos professores efetivos de cada uma delas, além do professor-pesquisador em estágio docente, ao longo de todo ano letivo.

O Ateliê Digital Integrado foi composto por 15 alunos do primeiro ano e mais 17 do segundo ano que haviam cursado a disciplina em 2016, conforme descrito por Maciel (2019). As atividades foram realizadas nas instalações do $\mathrm{LCAD}^{4}$, utilizando uma sala de aula organizada para realizar discussões e apresentações com a participação de todo o grupo e duas salas de informática ao lado desta, com computadores para o desenvolvimento individual ou em grupo das atividades práticas. Como proposta didática, o Ateliê Digital Integrado focou na realização do maior número possível de exercícios, em crescente grau de dificuldade, explorando ao máximo os conteúdos da disciplina, seguindo a mesma abordagem metodológica focada no aluno, adotada na disciplina em 2016, e sumarizada a seguir:

- As aulas expositivas sempre curtas em linguagem direta, de forma que o conteúdo fosse facilmente entendido e assimilado pelos alunos sem dificuldades. Quando necessário, o aprofundamento daquele conteúdo era feito em exercícios subsequentes;

- Pesquisas sobre o tema do exercício projetual e de obras de referências realizadas de forma autônoma pelos alunos na $w^{2} b^{5}$, selecionando obras de arquitetos de suas preferências, segundo suas crenças e valores;

- A construção de modelos geométricos das propostas projetuais e a produção de desenhos técnicos utilizando o computador como principal recurso para a representação arquitetônica;

- A apresentação de todas as propostas (primeiros estudos e solução final) projetuais desenvolvidas pelos alunos em seminários, com o uso projetor multimídia para ampla discussão, em momentos de orientação coletiva.

O curso contou com um ambiente virtual de apoio a aprendizagem (Moodle), onde eram postadas pelos professores, as orientações para as atividades e pelos alunos os resultados parciais e finais dos trabalhos desenvolvidos. Além disto, vasto material bibliográfico sobre os temas discutidos em sala foi disponibilizado para os estudantes. 
Para que o curso fosse viabilizado, foi desenvolvido um conjunto de atividades introdutórias e complementares que envolveram: a construção de mapas mentais e conceituais como ferramentas para sistematizar e explicitar o conhecimento construído; noções e exercícios de Ergonomia; oficinas de croquis e oficinas de modelagem geométrica. Para a modelagem geométrica inicialmente utilizou-se o SketchUp e posteriormente, de forma complementar, o Rhinoceros e o Grasshopper para modelagem de formas complexas. Essa abordagem com softwares de diferentes escalas de complexidade e interatividade é descrita por Gebran (2009), como uma oportunidade de enriquecimento na relação professor/aluno e é favorável ao processo criativo. Também foram realizadas aulas específicas, segundo a necessidade de determinadas atividades, sobre temas diversos como introdução ao paisagismo e ao conforto ambiental, por professores e palestrantes convidados.

As avaliações de aprendizagem do Ateliê Digital Integrado foram realizadas levando em consideração as notas obtidas nos seminários e as notas dos projetos impressos, com atribuição de pesos de 4 e 6 respectivamente. As atividades realizadas no primeiro e segundo semestres também tiveram peso diferenciado, sendo 4 para o primeiro e 6 para o segundo semestre. Para os seminários, foram avaliadas as informações pesquisadas, a organização das informações para a projetação, a qualidade das propostas e a clareza da apresentação oral e gráfica do projeto. Os projetos impressos foram avaliados considerando a qualidade da solução proposta e a clareza e completude da representação técnica, que deveria ser adequada para cada fase da projetação nas diferentes turmas, como explicitado a seguir.

$\mathrm{Na}$ turma de Ateliê I foram desenvolvidas propostas projetuais em nível de estudo preliminar. Para analisar a qualidade arquitetônica dos trabalhos, foram verificadas a compreensão do problema e a distribuição espacial da solução. Ainda, o atendimento às questões postas com relação ao programa, restrições, aspectos legais e da projetação. Foram verificadas questões sobre abordagem conceitual da proposta e viabilidade do sistema construtivo. Especial cuidado foi dado à representação arquitetônica, uma vez que o ensino deste conteúdo é responsabilidade da disciplina. Já na disciplina Ateliê II foram desenvolvidas propostas projetuais em nível de anteprojeto, com o estudo da solução estrutural, da circulação vertical, do dimensionamento de reservatórios, lançamento de pontos de iluminação e tomadas e outros requisitos técnicos compatíveis com o nível da disciplina.

As pranchas de desenhos impressas ou em formato digital (.pdf) eram entregues pelos alunos uma semana após os seminários, de forma que eventuais correções/sugestões pudessem ser incorporadas na entrega final trabalhos. Todas as pranchas foram corrigidas e anotadas pelos professores, e devolvidas aos alunos de forma que pudessem absorver as críticas e sugestões. Os seminários estimulavam o estudante a explicar e defender em público sua proposta, ampliando seu vocabulário técnico e permitiam que todos tivessem contato com diferentes propostas para um mesmo problema, aumentando também o repertório de possíveis soluções.

\section{As atividades}

É importante ressaltar que alguns exercícios foram realizados conjuntamente pelas duas turmas (por exemplo, oficina de croqui, todos os seminários para apresentação e discussão dos trabalhos e algumas atividades de projeto mesclando as duas turmas). Outros exercícios foram realizados separadamente por cada grupo (por exemplo, as atividades de ergonomia e de oficina de modelagem no SketchUp só foram realizadas para o grupo de Ateliê I, já que os alunos do Ateliê II haviam participado no ano anterior destas atividades). As atividades propostas para o Ateliê Digital Integrado tiveram um crescente aumento na complexidade dos conteúdos abordados e nos problemas propostos. Elas foram agrupadas em (1) atividades introdutórias e (2) atividades de projeto. O Quadro 1 mostra as atividades introdutórias do Ateliê Digital Integrado. 


\begin{tabular}{|c|l|l|}
\hline \multirow{2}{*}{ Atividade } & \multicolumn{2}{|c|}{ Ateliê Digital Integrado (2017) } \\
\cline { 2 - 2 } & \multicolumn{1}{|c|}{ Ateliê I } & \multicolumn{1}{|c|}{ Ateliê II } \\
\hline 1 & $\begin{array}{l}\text { Pesquisa e apresentação em sala sobre arquiteto de referência e sua obra: arquiteto } \\
\text { nacional e estrangeiro }\end{array}$ \\
\hline 2 & Oficinas de Croqui & Início das atividades de projeto \\
\hline 3 & Criação de mapas mentais e conceituais \\
\hline 4 & Ergonomia & \\
\hline
\end{tabular}

Quadro 1: Atividades introdutórias do Ateliê Digital Integrado

Fonte: Os autores.

Foi realizada uma oficina de croqui com duração de 12 horas (3 aulas), para todo o grupo de alunos, com o objetivo de explorar a expressão e a representação à mão livre, considerada fundamental por parte dos professores. Uma das seções foi realizada por professores da disciplina e outras duas com professores convidados. A Figura 1 mostra dois exercícios realizados em uma das oficinas, fundamentados no trabalho de Edwards (2005). Nas outras oficinas foram explorados princípios teóricos e práticos do desenho em perspectiva, além de tópicos como tipos de linhas, valores tonais, dentre outros, trabalhados em sala de aula e em ambientes externos.
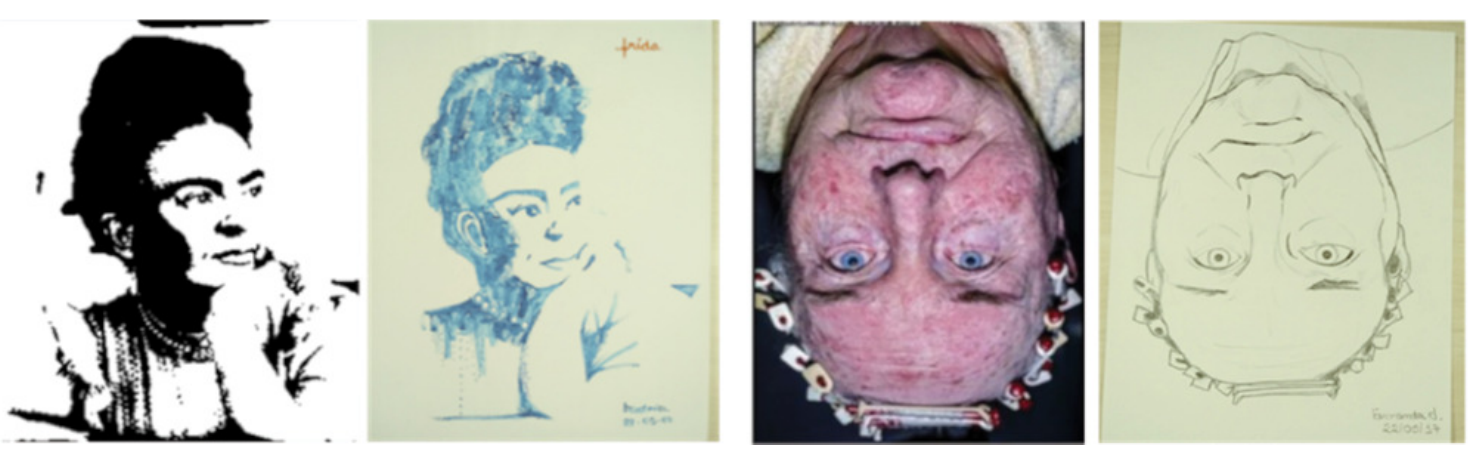

Figura 1: Atividade de croqui, baseada em Edwards (2005)

Fonte: trabalhos realizados por Beatrice Santiago (a); e Fernanda Vitória (b), ambas do Ateliê II.

Já a Figura 2, mostra outro tipo de exercício: desenho em perspectiva de espaços da FAUFBA.
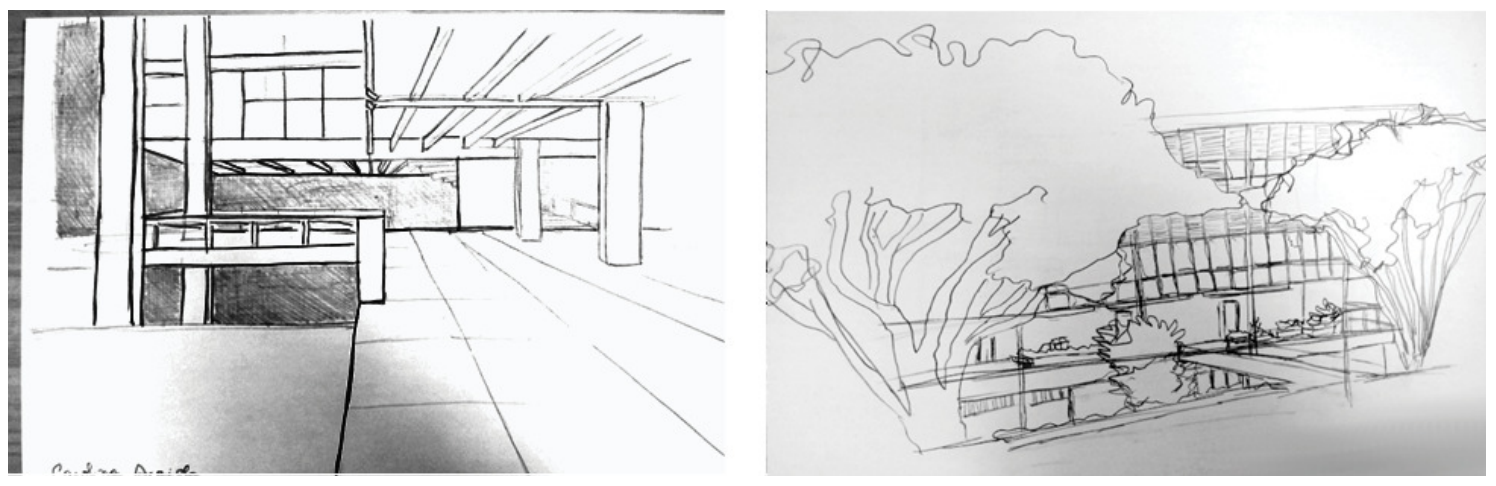

Figura 2: Atividade de croqui na FAUFBA

Fonte: elaborados pelas alunas Carolina Acaiah, Ateliê I, (a); e Adaildes Nascimento, Ateliê II (b). 
Outras atividades, como a elaboração de mapas mentais e mapas conceituais, serviram para que os alunos pudessem explicitar os conhecimentos adquiridos nas pesquisas realizadas, assim como organizar as informações em cada atividade solicitada. As atividades de ergonomia (Ateliê I) tiveram como objetivo apresentar a relação entre o corpo humano e as tarefas do cotidiano, fossem elas de trabalho ou lazer. A Figura 3, mostra um exercício em que os alunos apresentavam um mapa conceitual sobre Projeto de Arquitetura e a Figura 4 mostra o exercício em que foi solicitado que os estudantes avaliassem a ergonomia de um posto de trabalho de sua residência.
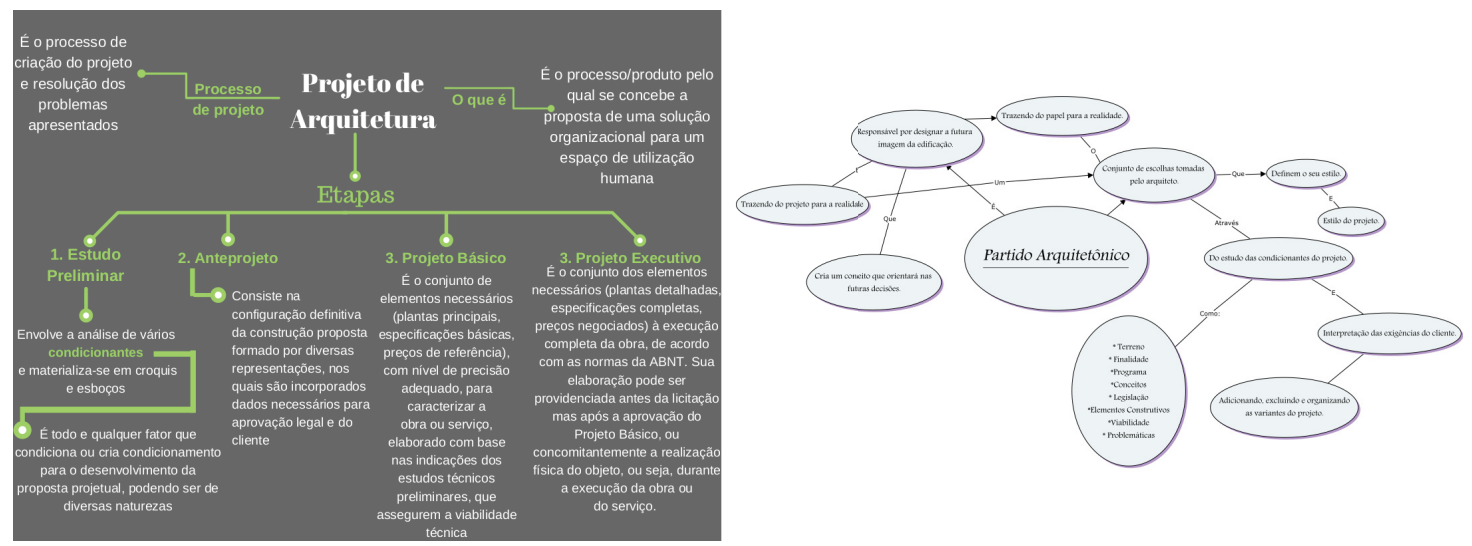

Figura 3: Atividade sobre projeto de arquitetura

Fonte: trabalhos realizados pelas alunas Ariane Santana (a); e Gabrielle Sacramento (b), ambas do Ateliê I.

\section{DESCRIÇÃO DO POSTO dE TRABALHO}
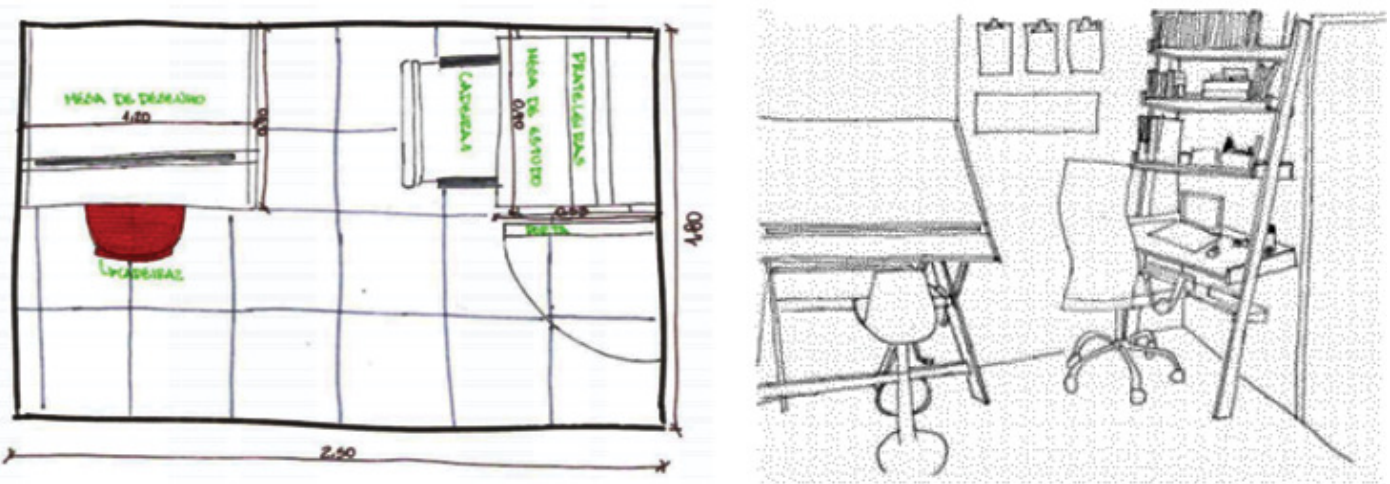

Figura 4: Atividade de ergonomia

Fonte: trabalho realizado pela aluna Bruna Santos, Ateliê I.

A oficina de modelagem foi dedicada apenas aos alunos do Ateliê I e durou 3 aulas. Seu objetivo foi apresentar o SketchUP, como principal ferramenta de modelagem a ser utilizada nas atividades projetuais. Foram apresentados conteúdos preliminares como a operação de extrusão; a organização/estruturação do modelo empregando "grupos" e "planos de informação"; a visualização em perspectiva paralela e perspectiva cônica; a utilização da ferramenta para criar seções sobre o modelo; a criação de cenas com vistas escolhidas para a apresentação do projeto; a aplicação de materiais e definição de estilos de apresentação; o georreferenciamento do modelo e ferramentas de inserção de sombras e impressão dos desenhos em escala (plantas, vista, cortes e perspectivas: externas e internas). 
Ainda, durante a oficina, foi mostrado aos alunos, como extrair os desenhos de representação da arquitetura diretamente do modelo para a montagem das pranchas de desenho. Para esta atividade foram utilizados dois programas auxiliares: um gerador de PDF gratuito (CutePDF writer), para exportar desenhos em escala a partir de cenas do SketchUp e o Inkscape, programa livre de desenho vetorial, para a construção de folhas, carimbos, anotações e outros pormenores que complementavam a representação técnica. Na oficina de modelagem, foi destinado um tempo menor para a apresentação dos diversos estilos de representação, sendo dedicado um tempo maior ao processo de exportação dos desenhos em escala e na montagem das pranchas de desenho. Isto deveu-se ao fato de que esta atividade foi vista como mais difícil e trabalhosa para os alunos do Ateliê I em 2016. A Figura 5 mostra resultados do exercício realizado na Oficina de SketchUp.
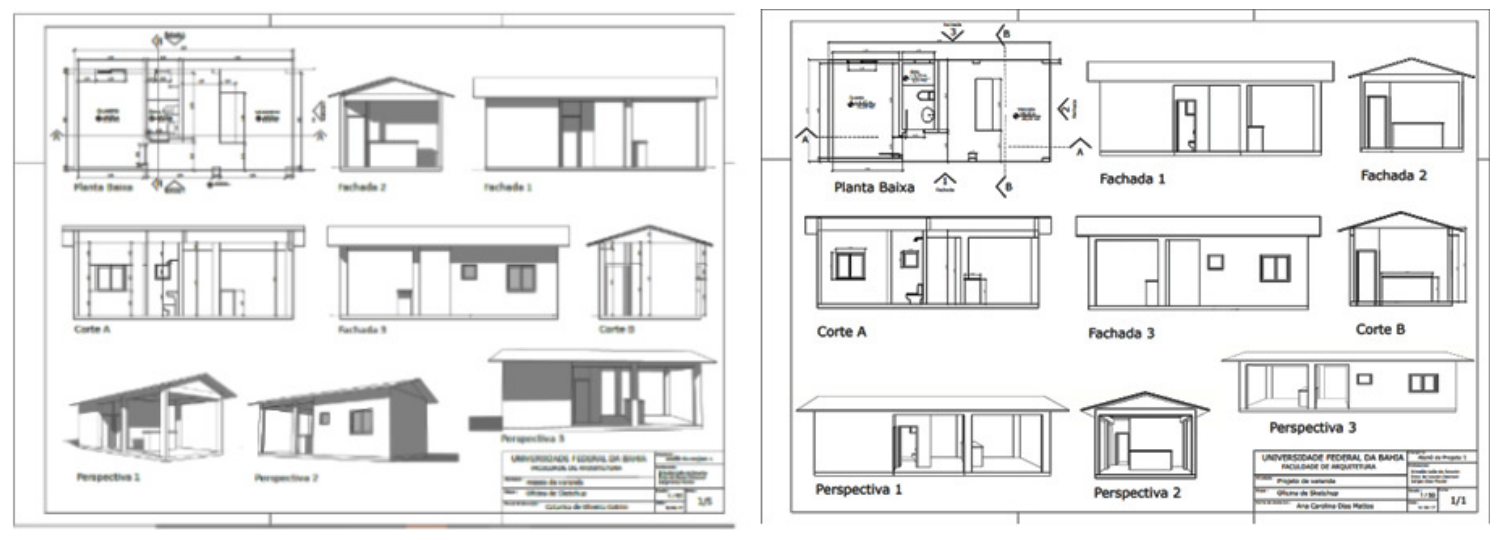

Figura 5: Oficina de SketchUp

Fonte: pranchas de Catarina Cotrim (a); e Ana Carolina Mattos (b), ambas do Ateliê I.

A necessidade de dar subsídios para os alunos representarem formas complexas, percebida pelos professores em 2016, fomentou a criação de cursos introdutórios de Rhinoceros e Grasshopper entre os semestres letivos do ano. O curso realizado em 2016, teve 40 horas de duração e visou a apresentação de uma nova ferramenta e forma de projetar, bem como a ampliação do repertório digital, conforme descrito por Oxman (2008), incorporando conceitos e elementos do digital design, como por exemplo o uso de 'voronoi' ${ }^{6}$ ' e 'paneling'? . Ainda, foi oferecida uma introdução ao plug-in LadyBug8. Já no curso de 2017, a duração foi de 24 horas e foco na utilização do plug-in Lunchbox 9 , para facilitar a criação de estruturas planas e espaciais, e assim, atender mais especificamente a criação de superfícies para coberturas. Outra prioridade do curso de 2017 foi a exportação das soluções criadas no Rhinoceros e no Grasshopper para o SketchUp. A Figura 6 mostra um exemplo dos exercícios desenvolvidos por alunas do Ateliê I.
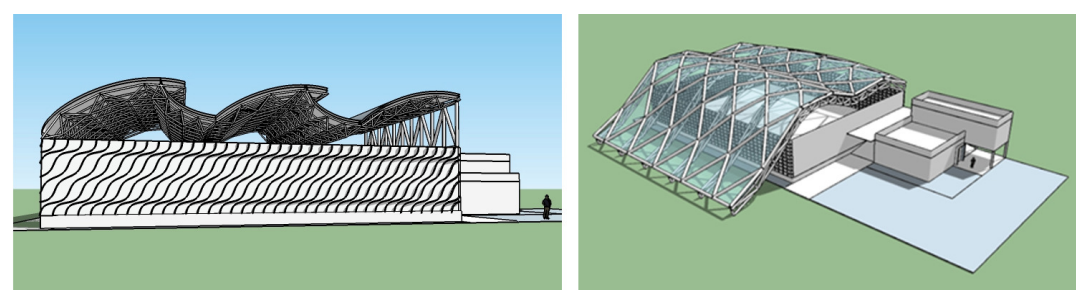

Figura 6: Atividades no Rhinoceros e Grasshopper

Fonte: trabalhos realizados por Ariane Puridade (a); Bruna Nascimento (b), do Ateliêl.

$\begin{array}{cc}6 & \text { Um diagrama de Voronoi consiste na divisão de um espaço em células contíguas com um ponto } \\ \text { Todos os pontos internos à célula possuem maior proximidade de seu ponto interno central que da célula vizinha } & \end{array}$

7 Um paneling consiste na distribuiçăo de uma determinada forma geométrica repetidamente sobre uma superfície. Plug-in do Grashopper que importa arquivos do padrão EnergyPlus Weather (.EPW) e realiza análises de dados climáticos, auxiliando em estudos de sombreamento e radiação solar, dentre outros que podem auxiliar na tomada de decisões projetuais. $\quad$ Plug-in do Grashooper que disponibiliza um conjunto de ferramentas para criação de formas baseades em fórmulas matemáticas, como voronoi; dividir objetos de diferentes maneiras, criando paneling, elementos estruturais, dentre outros. 


\section{As atividades de projeto}

Com relação aos projetos, foram desenvolvidas seis atividades com a turma Ateliê I e seis atividades com a turma Ateliê II, sendo que uma atividade foi realizada com ambas as turmas simultaneamente. Com relação aos objetivos didáticos e pedagógicos, as atividades da turma Ateliê I estiveram mais voltadas para o ensino de representação arquitetônica e a introdução à projetação, sendo exigidos os conceitos para a apresentação dos trabalhos em nível do estudo preliminar, enquanto as atividades da turma Ateliê II estiveram voltadas ao aprofundamento da projetação, com apresentação dos trabalhos em nível de anteprojeto. As atividades realizadas são apresentadas no Quadro 2:

\begin{tabular}{|c|l|l|}
\cline { 2 - 3 } Atividade & \multicolumn{2}{c|}{ Ateliê Digital Integrado (2017) } \\
\cline { 2 - 3 } & \multicolumn{1}{|c|}{ Ateliê I (temas) } & \multicolumn{1}{c|}{ Ateliê II (temas) } \\
\hline 1 & Mobiliário urbano & Residência Universitária \\
\hline 2 & Praça & $\begin{array}{l}\text { Escolher um trabalho do ano anterior (Estudo } \\
\text { preliminar) e desenvolver em nível de anteprojeto }\end{array}$ \\
\hline 3 & Galpão & Escola \\
\hline \multicolumn{3}{|c|}{ Recesso entre os semestres } \\
\hline 4 & Residência & Diagnóstico urbano \\
\hline 5 & Projeto de edifício misto (atividade comum) \\
\hline 6 & Capela & Centro cultural \\
\hline
\end{tabular}

Quadro 2: Atividades de projeto no Ateliê Digital Integrado

Fonte: elaborado pelos autores.

Todas as atividades de projeto foram definidas de modo que houvesse temas relacionados aos espaços arquitetônicos e urbanos, que foram trabalhados segundo a sua complexidade, em grupo ou individualmente. Para cada atividade foi criado um edital com orientações sobre a mesma e seus objetivos, que foi discutido em sala de aula e disponibilizado no Moodle, com acesso a todos os alunos. No Ateliê Digital Integrado, foram realizadas as mesmas rotinas da projetação do ano 2016, com pesquisas sobre os temas, elaboração de programa de necessidades, pré-dimensionamento, utilização de diagramas (funcionogramas e fluxogramas) e definição do partido arquitetônico. Os resultados dessas rotinas iniciais eram apresentados nos seminários com objetivo de fomentar discussões para posteriormente, contribuir com correções na apresentação do projeto impresso. A Figura 7 mostra um exemplo de exercício desenvolvido por uma dupla do Ateliê II.
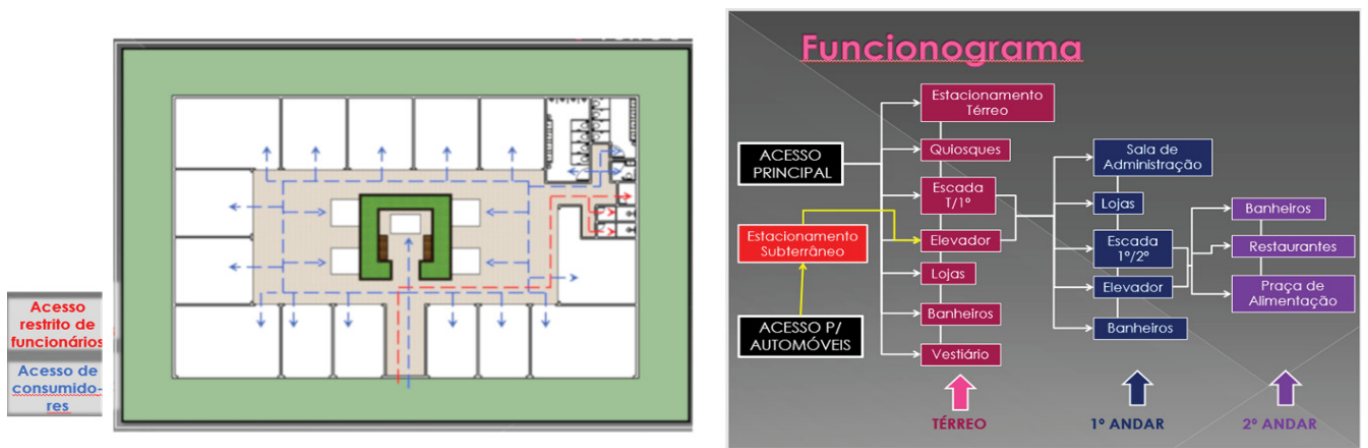

Figura 7: Estudos iniciais na projetação

Fonte: trabalhos realizados pelas alunas Álika Áquila (a); e Ângela Lima (b), ambas do Ateliê II. 


\section{Dificuldades iniciais na projetação em ambiente digital}

As maiores dificuldades, ocorridas na turma de 2016, foram com relação a erros de representação arquitetônica e problemas causados pela falta de experiência no uso do SketchUp. Os erros mais comuns foram os relacionados à cotagem dos desenhos e na hierarquia das linhas na visualização dos modelos cortados e em vista. No ano de 2017, os alunos foram alertados para as dificuldades já detectadas e superaram a expectativa com relação aos problemas de modelagem e cotagem.

Foram também verificados problemas com relação ao excesso de modelos acessórios (componentes arquitetônicos), inseridos nos projetos pelos alunos através do recurso 3D Wharehouse, do próprio SketchUp. Estes modelos eram usados, muitas vezes, para compor o ambiente criado, mas tornavam confusa ou incorreta a representação técnica do projeto, por incorporarem a representação elementos secundários em escalas inadequadas, sem a correta diferenciação de linhas e cores. A Figura 8 mostra dois exemplos onde em (a), existe problema na representação do piso e em (b), problema com a quantidade de componentes (decorativos) inseridos na proposta arquitetônica.
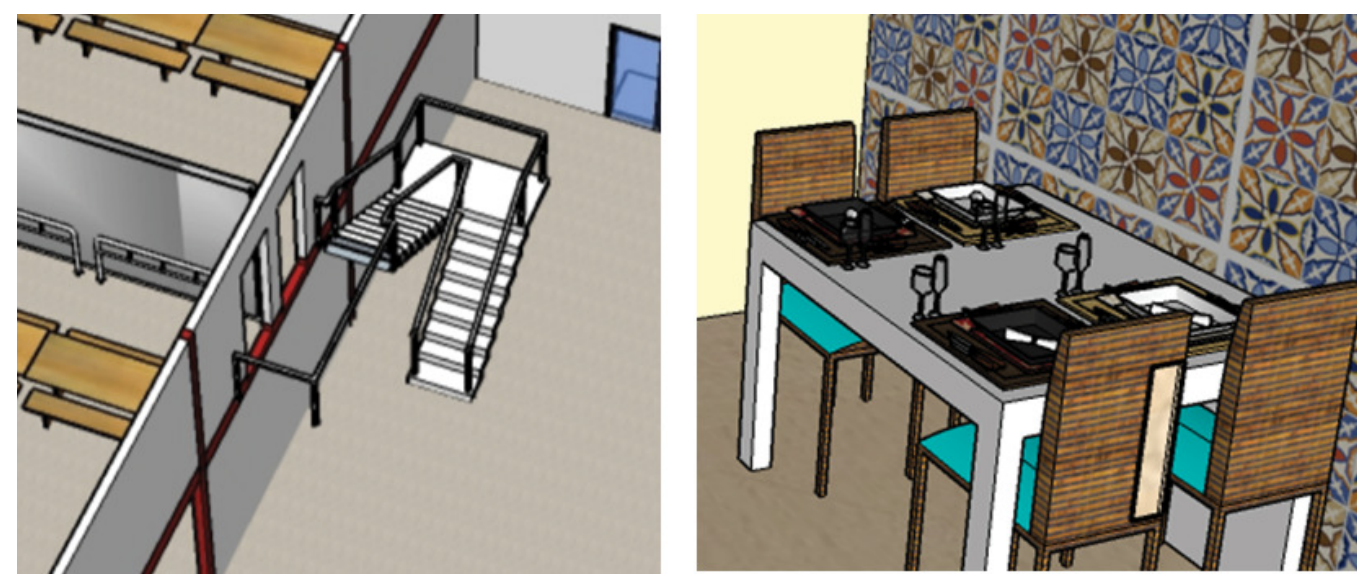

Figura 8: Problema de modelagem: falta o piso (a); inserção excessiva de objetos no modelo (b) Fonte: trabalhos realizados por alunos do Ateliê I.

Outros erros verificados decorreram da facilidade de uso do SketchUP, trazendo prejuízo à projetação e à representação técnica. Em algumas situações, os alunos não fizeram as tradicionais seções no modelo para gerar as plantas baixas ou os cortes, transgredindo a forma de representação correta, seja pela captura de imagem na tela (utilizando o recurso "print screen") ou pela utilização de transparência no modelo, para "representar" seu interior. A Figura 9 ilustra dois exemplos destes equívocos, sendo que em (a) a captura da tela não mostra as aberturas (portas e janelas) e em (b) a utilização inadequada da transparência para representar o interior da construção, ao invés do corte.

As dificuldades foram sendo superadas a cada exercício realizado e, ao final, apenas a dificuldade em relação a hierarquia de linhas manteve-se com maior ocorrência, devido à falta de experiência tanto na representação arquitetônica quanto no manuseio do software, que demandam maior refinamento e atenção. 

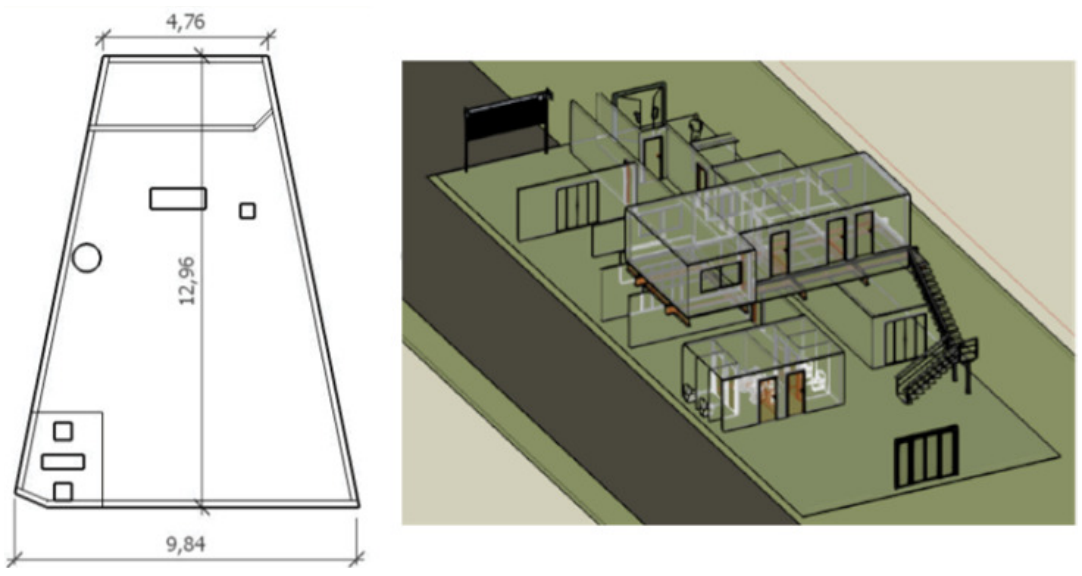

Figura 9: Erros na representação arquitetônica

Fonte: trabalhos realizados por alunos do Ateliê I.

\section{Aspectos positivos na projetação em ambiente digital}

Além dos recursos tecnológicos, importantes ferramentas para projetação descritas por Hemi e Fraser (1994) e Lawson (1999) foram utilizadas no curso, como os croquis. A Figura 10 mostra um exercício realizado com a combinação de recursos.

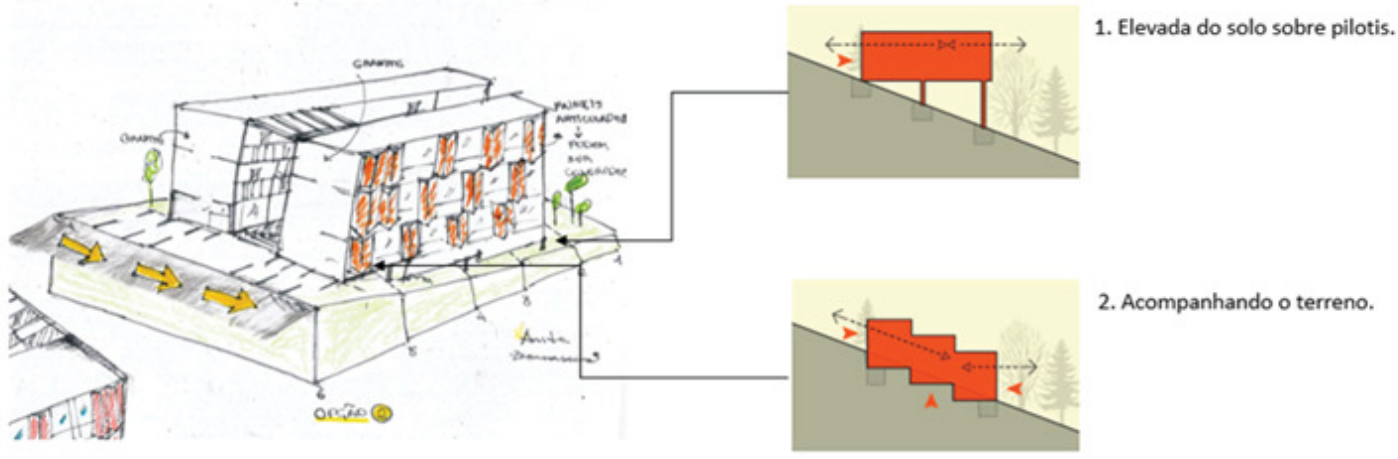

Figura 10: Combinação de recursos usados na projetação

Fonte: elaborado pela aluna Adaildes Nascimento, do Ateliê II.

Mais uma vez, as vantagens do uso do computador desde as etapas iniciais do curso ficaram evidentes já nas primeiras atividades. As discussões não se resumiram somente às questões de representação de vedações, estruturas, coberturas e outros elementos do projeto, mas enfocaram a intenção do aluno ao criar o espaço e sua ambientação. Questões técnicas, construtivas e sobre a qualidade da edificação proposta eram discutidas sobre o modelo geométrico apresentado pelo estudante, auxiliando-o no seu amadurecimento sobre as diferentes variáveis que envolvem a projetação arquitetônica.

A representação através dos modelos geométricos auxilia na maior compreensão do projeto desenvolvido pelo aluno-autor e pelo grupo que na discussão, também aumenta seu repertório projetual. Ainda, a inserção de imagens e texturas aplicadas ao modelo, acabamentos diferenciados e a variedade de opções a disposição do estudante também ajudaram na 
expressão da criatividade durante a elaboração das propostas projetuais. A Figura 11 mostra dois exemplos de exercícios que utilizaram texturas para auxiliar na representação do projeto.
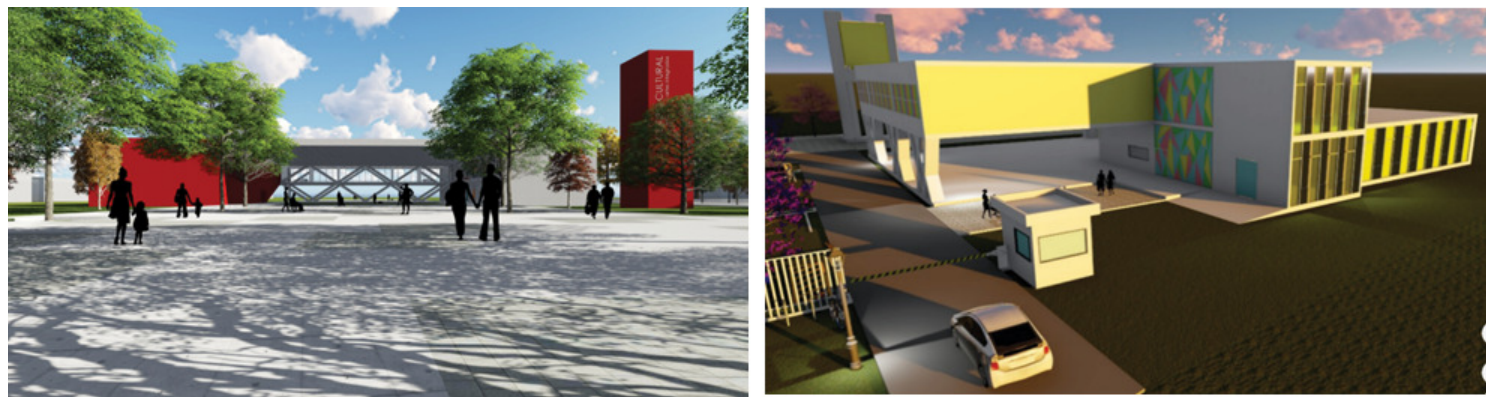

Figura 11: Uso de texturas para melhor compreensão e apresentação do projeto

Fonte: perspectivas/modelos elaborados pelas alunas Rafaela Tan (a); e Nicole Santos (b), ambas do Ateliê II.

Outra questão importante que ficou evidente relaciona-se com a variedade de opções e liberdade de escolha que os alunos tiveram para apresentar seus projetos. Foram utilizadas várias formas que incluíram desde croquis feitos à mão, ao estilo tradicional de utilização de sombras do SketchUP, renderização $\mathrm{NPR}^{10}$ e a renderização realística. Esse processo de experimentação foi mais lento na turma Ateliê I de 2016, com descobertas sucessivas e compartilhadas a cada nova atividade e mais dinâmico no Ateliê Digital Integrado, devido à proximidade entre as turmas em estágio de desenvolvimento distintos.

Nas oficinas de modelagem, não foi dado destaque à renderização realística dos modelos pois havia o receio de que os alunos destinassem maior tempo na escolha da apresentação do que na solução projetual, contudo foram explorados vários recursos de renderização NPR, existentes no SketchUp. A Figura 12, mostra diferentes tipos de apresentações realizados por uma aluna ao longo do Ateliê I, 2016 e Ateliê II, 2017, que mostram a sua evolução no uso dos recursos.
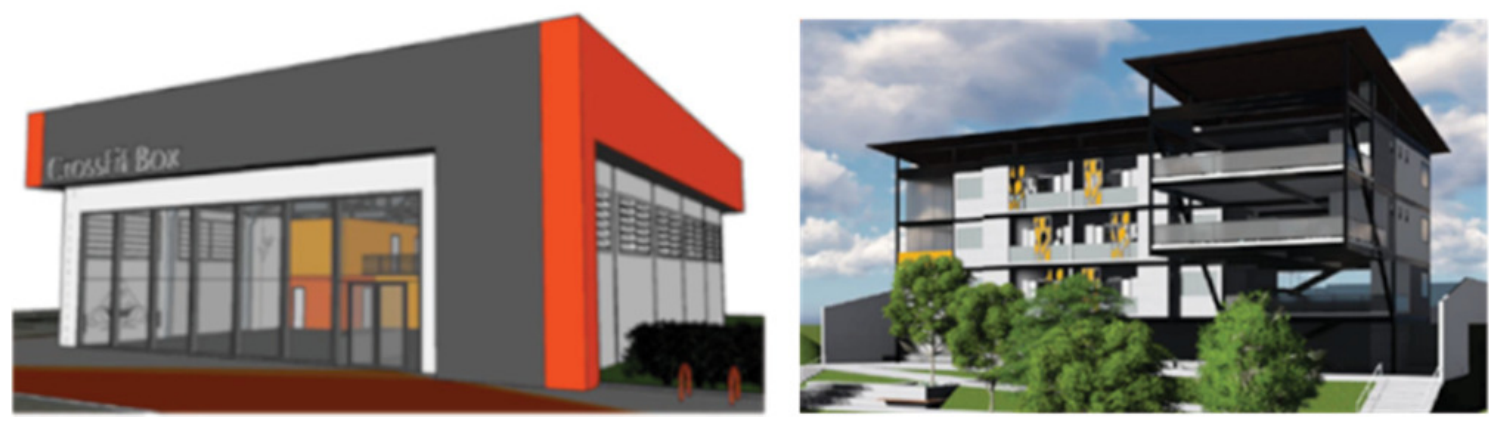

Figura 12: Diferentes recursos de apresentação em atividades diversas

Fonte: trabalhos realizados pela aluna Rafaela Tan (2016 e 2017). 
Além das várias possibilidades para a apresentação do projeto, o aprimoramento conseguido na modelagem ao longo das várias atividades permitiu desenvolver trabalhos com bons resultados na representação dos desenhos técnicos de arquitetura. A Figura 13 apresenta dois exemplos de trabalhos desenvolvidos, um em dupla formada por uma aluna de Ateliê II e um aluno de Ateliê I e outro desenvolvido por uma aluna de Ateliê II.
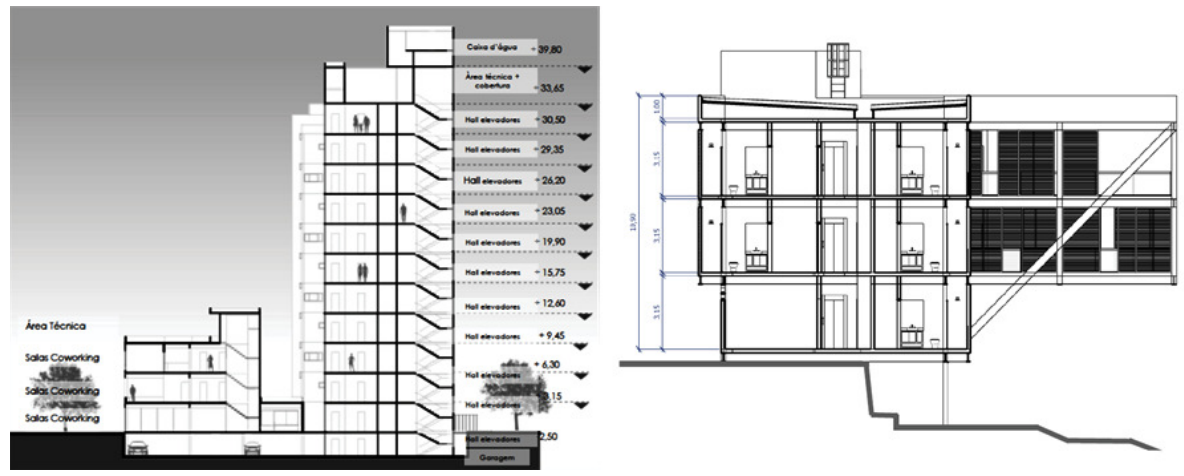

Figura 13: Bons resultados de representação arquitetônica

Fonte: trabalhos realizados pelos alunos Maria Luiza Santana e Rian Araújo (a), Ateliê Il e Ateliê I, respectivamente; Rafaela Tan (b), Ateliê II.

Figura 14: Exercícios de projeto de capela

Fonte: trabalhos realizados por Catarina Cotrim (a); e Carolina Acaiah (b), ambas do Ateliê I.
A discussão sobre a importância da solução estrutural na arquitetura pôde ser ampliada, ressaltando o que Silva (2003) definiu como projetualidade, que considera as diversas questões do contexto arquitetônico. As propostas dos estudantes eram realizadas de forma intuitiva e aproximada, a partir de pesquisas em projetos de referência nas atividades do Ateliê I e com maior profundidade nas desenvolvidas no Ateliê II. A turma de alunos ingressantes tinha possibilidade de se aprimorar ao ver os trabalhos desenvolvidos pelos colegas mais avançados no curso.

Apesar de não haver uma imposição sobre métodos que deveriam ser utilizados na projetação, constatou-se que as rotinas seguiam os mesmos princípios descritos por Broadbent (1973) e Rowe (1991), principalmente com a utilização de analogias e métodos canônicos. Estudos utilizando formas geométricas elementares, segundo Mitchell (2010), estudos sobre a composição, seguindo os mesmos princípios descritos de Mahfuz (1995), como utilização de princípios geométricos de organização e questões referentes a topologia entre as partes que constituem os projetos também foram soluções bastante abordadas na projetação pelos alunos.

Em algumas atividades, os alunos sentiram-se mais à vontade em explorar a forma como solução do partido arquitetônico. Na turma de Ateliê I a forma como partido arquitetônico foi mais evidente no projeto da capela (Figura 14), onde foram realizadas composições, segundo Mahfuz (1995), com princípios geométricos de organização, em relação a um ponto ou a uma linha.
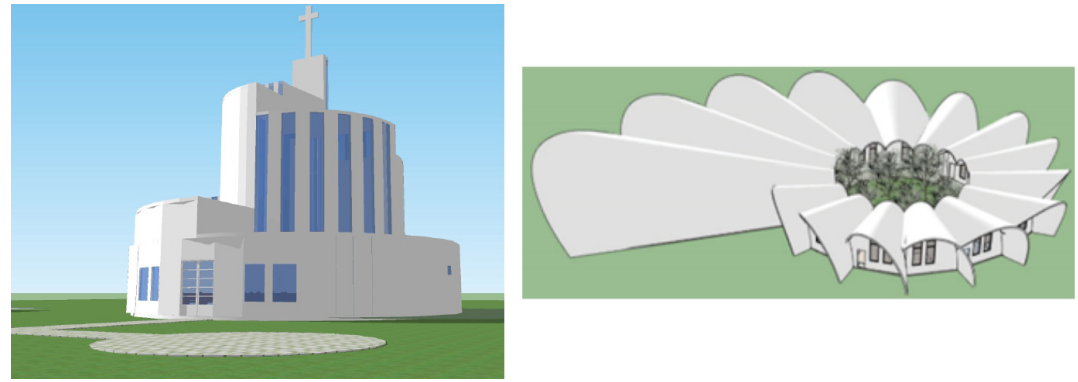
No Ateliê II as atividades atenderam a uma maior exigência nas informações (anteprojeto), sendo a concepção e a representação da estrutura exigidas em todos os exercícios projetuais. É importante destacar que no ensino do projeto, a construção do modelo geométrico ao invés do desenho tradicional, permite uma melhor compreensão da totalidade do projeto e suas implicações. A Figura 15 mostra exemplos de soluções estruturais apresentadas por alunos nos trabalhos realizados em dupla (Ateliê I e II).
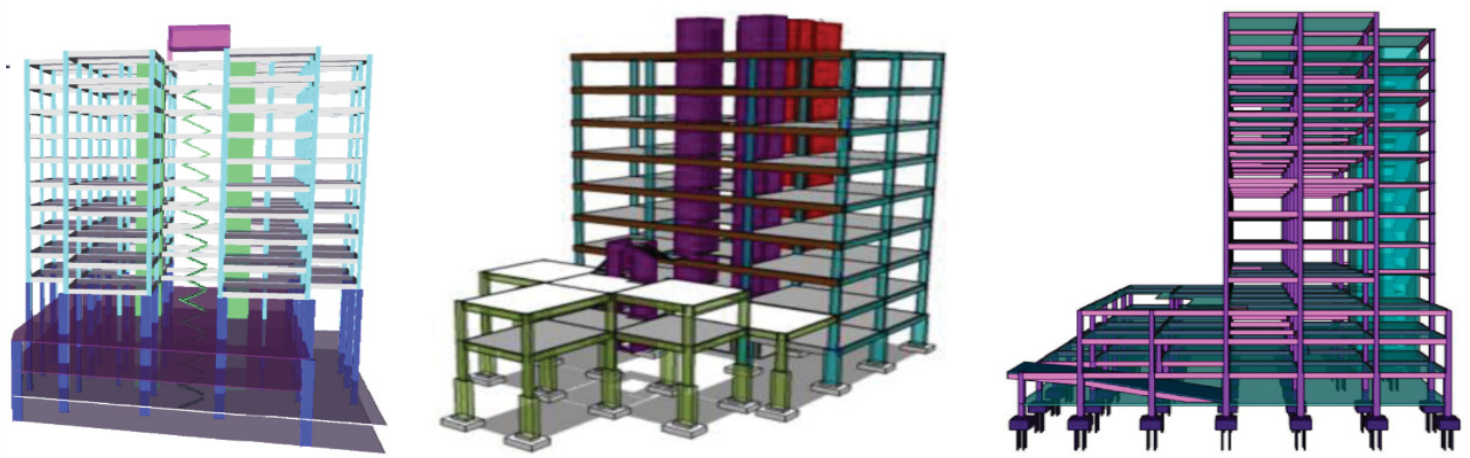

Figura 15: Estruturas em anteprojetos do Ateliê Digital Integrado

Fonte: trabalhos realizados pelos alunos Ana Clara Caribé e lasmine Leal (a); Rian Araújo e Maria Luiza Santana (b); Adriele Santana e Álika Áquila (c), em todos Ateliê I e Ateliê II, respectivamente.

A forma também ganhou destaque quando foram concebidas a arquitetura e a estrutura conjuntamente, sendo determinantes para qualidade do projeto. A Figura 16 mostra algumas formas arquitetônicas que tiveram a estrutura como ponto relevante na sua concepção, num exercício do Ateliê II, quando foi proposto um centro cultural.
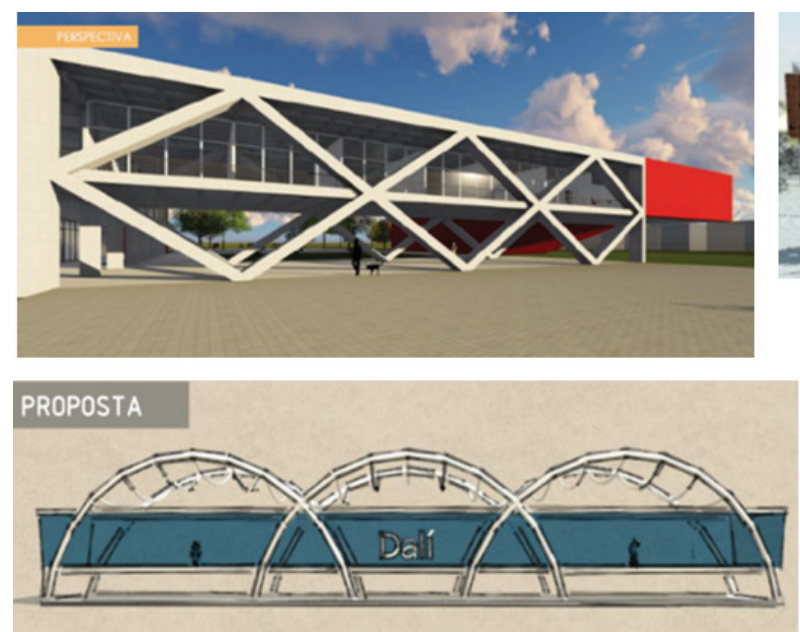
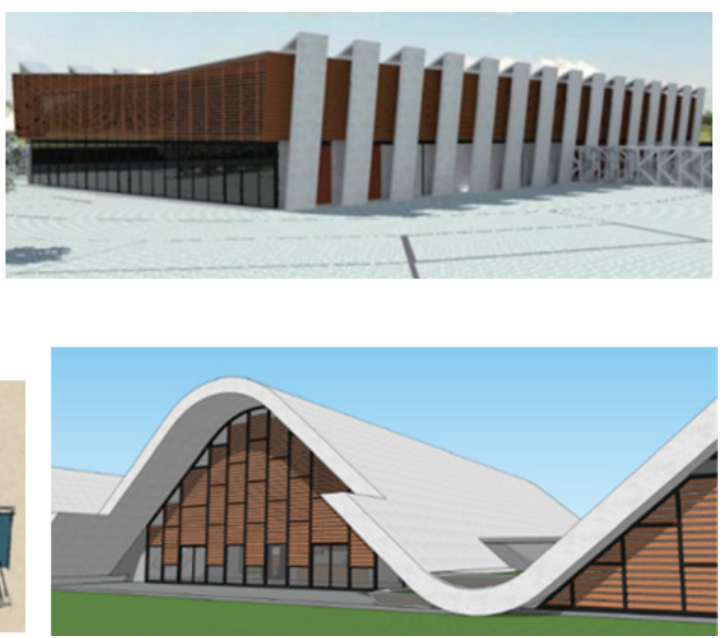

Figura 16: Formas estruturais determinantes do partido arquitetônico adotado

Fonte: trabalhos realizados pelos alunos Rafaela Tan (a); Beatriz Barreto (b); Beatrice Santiago (c); e Cainan Veloso (d), todos do Ateliê II. 
Para o Ateliê II, além da concepção e o desenvolvimento da estrutura, foram dimensionados os reservatórios, o que levou os alunos a perceberam a importância de seu estudo pois a solução em alguns casos, demandou volumes significativos visíveis em fachadas e perspectivas, além de cuidados com relação aos seus acessos nas plantas de coberturas. Foram trabalhadas também questões relacionadas ao dimensionamento, solução e representação da circulação vertical em projetos de múltiplos pavimentos. Por fim, o lançamento de pontos de iluminação e tomadas permitiu novas abordagens pedagógicas sobre a importância da luminotécnica na constituição dos ambientes.

\section{Uma atividade comum entre as duas turmas}

A turma Ateliê Digital Integrado favoreceu a realização de uma atividade comum entre as turmas Ateliê I e Ateliê II, cujos alunos encontravam-se em diferentes estágios de aprendizado. A atividade, que tinha como objetivo a proposta de requalificação e adensamento populacional de um trecho da orla de Salvador, foi motivada pelo novo plano de desenvolvimento urbano do município, Lei 9.069/2016 (PDDU) e Lei 9.148/2016 (LOUOS).

No caso, a atividade foi planejada para proporcionar aos alunos uma experiência ampla e significativa, indo desde o levantamento de informações em campo até a projetação em grupo, envolvendo aspectos urbanísticos e arquitetônicos e para tal, foram formadas equipes de dois alunos compostas por um aluno do Ateliê I e outro do Ateliê II. Nesta atividade, o uso do computador facilitou a organização e o compartilhamento das informações e a produção de documentação com a padronização da representação arquitetônica

Desta forma, a atividade contou com as seguintes etapas:

- Palestra de uma arquiteta convidada que expôs sobre a nova legislação urbana e suas particularidades, especialmente com relação às questões que envolviam a verticalização da orla;

- Trabalho de campo para reconhecimento do local, mapeamento dos imóveis existentes segundo tipologia, gabarito e usos no local, onde cada grupo ficou responsável pela verificação de uma quadra do trecho da orla;

- $\quad$ Elaboração de um mapa base, a partir do levantamento de campo, sintetizando o estado de conservação dos imóveis, o uso e a ocupação do solo no trecho estudado;

- Remembramento e homogeneização das áreas dos lotes em algumas quadras, com a finalidade de um melhor aproveitamento, e adequando-os à uma nova proposta urbanística, eliminando lotes muito pequenos. Na sequência foi feito o sorteio dos novos lotes com as equipes, sendo livre escolha das mesmas as novas tipologias a serem projetadas, objetivando maior adensamento populacional da área e o uso continuado da mesma durante o dia todo. No caso, foi sugerido aos alunos que escolhessem temas que promovessem a permanência de pessoas na região em todos os períodos do dia e nesse caso, foram escolhidos por parte dos alunos, tipologias como habitação multifamiliar em prédios de usos mistos (multifamiliar e serviços) e hotel e,

- Projetação segundo a nova legislação local.

A Figura 17 mostra a configuração atual do trecho (a), e o levantamento realizado pelos alunos (b), discriminando as construções e seus usos. 


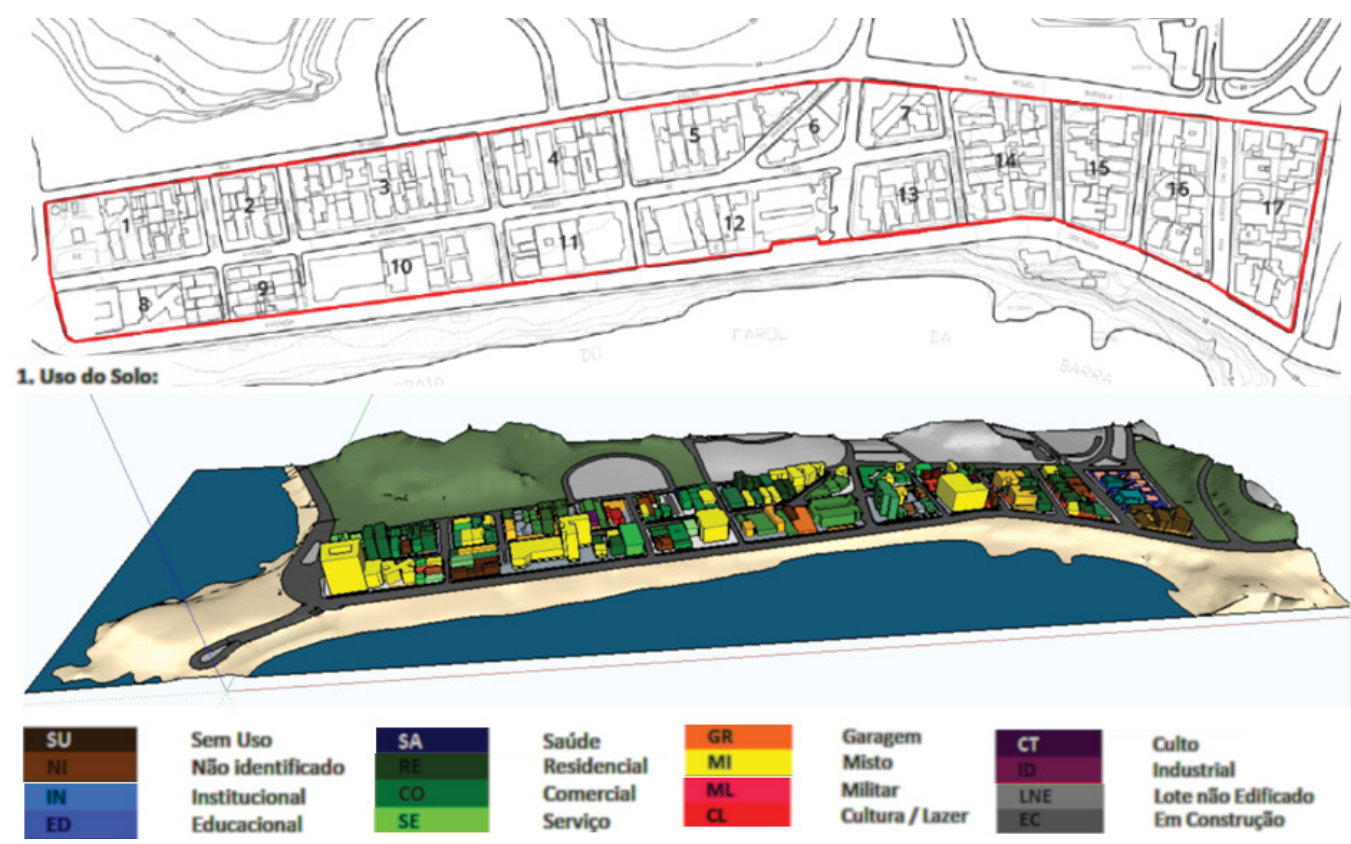

Figura 17: Trecho para da orla para atividade

Fonte: trabalho realizado pelo conjunto de alunos.

O remembramento dos lotes e os novos estudos de uso previram o aumento da densidade habitacional, segundo o incremento da verticalização no local, nos limites estabelecidos pela legislação urbanística vigente. A verticalização foi estudada segundo as novas diretrizes de modo que não houvesse prejuízo quanto a obstrução do sol nas praias (exceto no período do inverno) e assim, foram realizados estudos de insolejamento. Nesse caso, o georreferenciamento do modelo no SketchUp e a realização de análises do sombreamento produzido pelas edificações propostas na praia foram importantes recursos utilizados. A Figura 18 mostra o trabalho de uma aluna de Ateliê I e uma aluna de Ateliê II apresentando um trecho da orla de Salvador, com simulação de sombras.

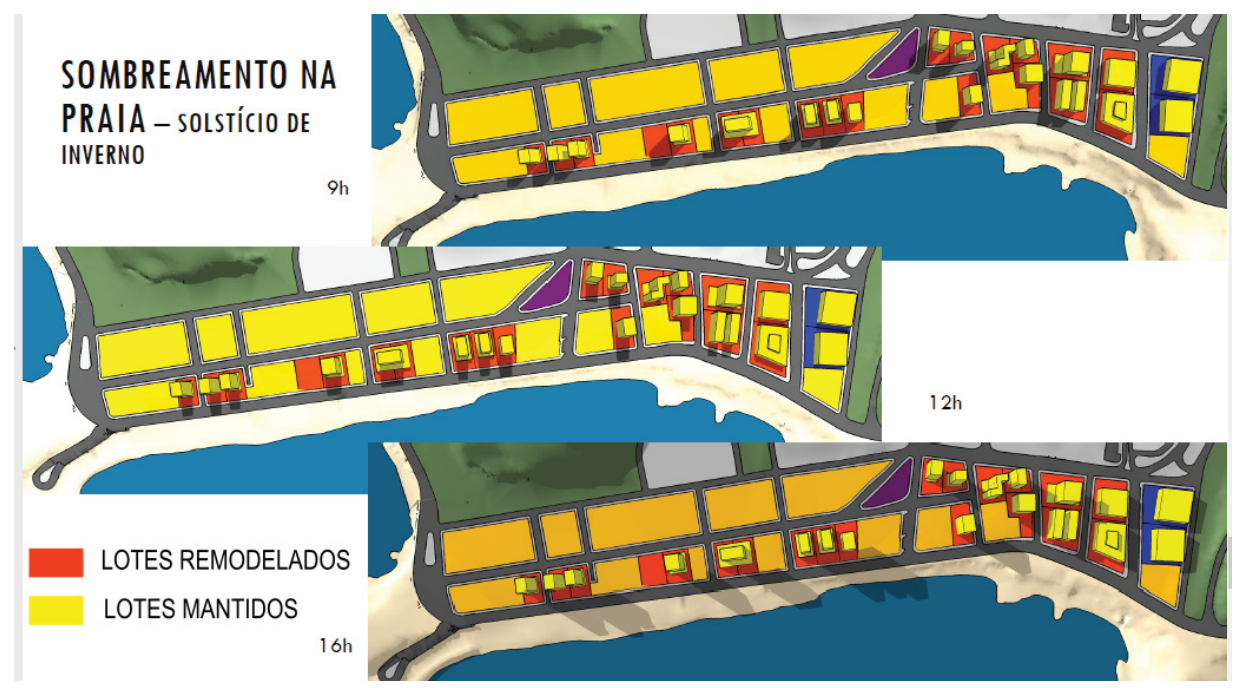

Figura 18: Uso de recursos de georreferenciamento e insolejamento aplicados na projetação

Fonte: trabalho realizado pelas alunas Bruna Ferreira e Beatriz Magalhães, Ateliê I e Ateliê II respectivamente. 
Após o redesenho dos lotes, houve o sorteio para que cada dupla desenvolvesse seu projeto segundo novos usos, por exemplo habitação multifamiliar e prédios de uso misto. A Figura 19 mostra um edifício de uso misto (residencial com uma galeria de arte), em (a); um edifício de uso misto (residencial com bloco de coworking), em (b); e um edifício exclusivamente residencial, em (c).
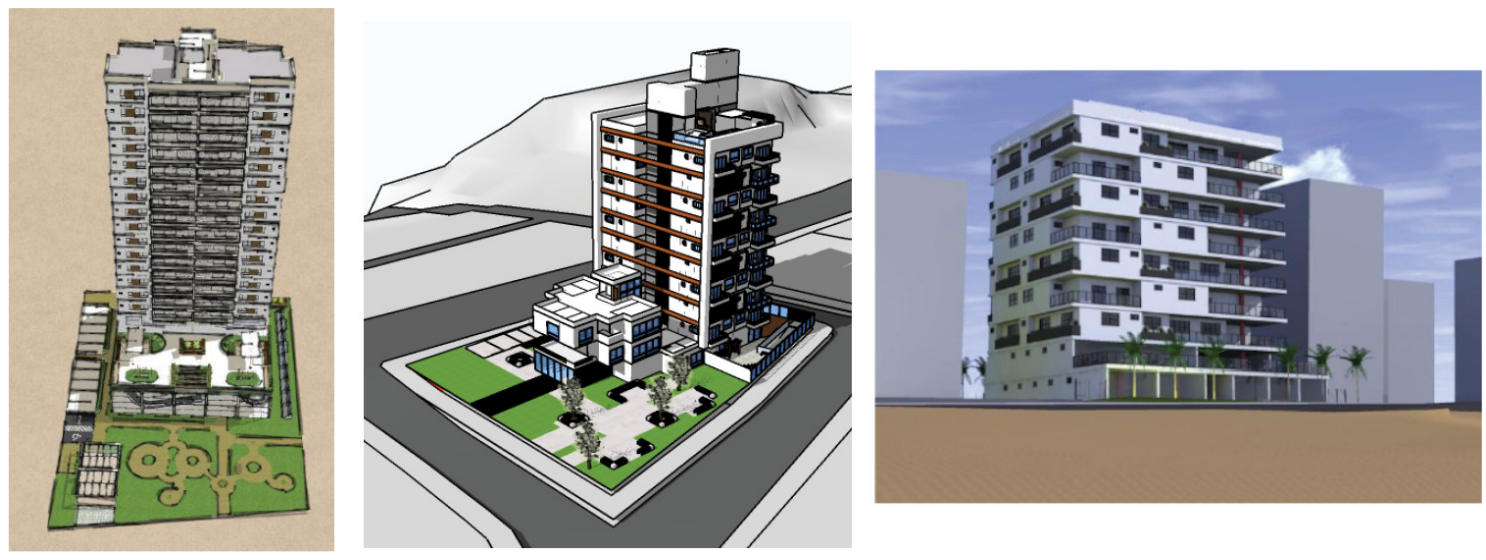

Figura 19: Projetos realizados nos lotes remembrados

Fonte: trabalho dos alunos Bruna Nascimento e Beatrice Santiago (a); Rian Araújo e Maria Luiza Santana (b); e Adriele Santana e Cainan Siqueira (c), Ateliê I e Ateliê II respectivamente.

Ao final da atividade as duplas haviam projetado edifícios para o trecho da orla em estudo, atendendo a nova legislação local. Como resultado positivo, destacou-se a complexidade da atividade envolvendo estudos urbanísticos e de projetação arquitetônica com variedade de usos, tipologias e gabaritos, compartilhando experiências e tornando a aprendizagem mais significativa.

\section{CONSIDERAÇÕES FINAIS}

O objetivo das turmas ofertadas, Ateliê Digital (2016) e Ateliê Digital Integrado (2017) foi ampliar a discussão sobre o ensino de projeto arquitetônico no contexto do desenvolvimento tecnológico atual. Nesse caso, a metodologia adotada procurou integrar o computador ao ensino da projetação arquitetônica em estágios iniciais da formação do estudante. Não se adotou o computador como único recurso didático, mas integrado as práticas usuais já adotadas, como por exemplo na pesquisa, na exploração da forma na composição arquitetônica, na expressão dos resultados alcançados e na integração de informações básicas de projetos de diferentes disciplinas. No desenvolvimento das atividades puderam ser observadas vantagens na utilização dos recursos digitais nas atividades propostas, tais como:

- Maior velocidade e precisão na produção de desenhos arquitetônicos a partir do modelo geométrico, favorecendo a realização de um maior número de atividades;

- Utilização de cores, materiais, texturas e diferentes tipos de representação;

- Estudos de planos de massas, com simulação de áreas iluminadas e de sombra e geração automática de perspectivas;

- Realização de pesquisas de referências em sala de aula, diretamente no computador antes e durante o processo projetual;

- Facilidade no compartilhamento de material entre alunos e 
professores;

- Ampliação das informações projetuais com a definição de elementos básicos dos projetos complementares;

- Utilização de programas auxiliares (plug-ins), quando necessários, para auxiliar a projetação.

O processo de modelagem através do SketchUp foi simplificado e demandou poucas horas para que os alunos conseguissem utilizar o programa de forma autônoma (12 h no total). As pesquisas de referências projetuais na web e a facilidade da modelagem geométrica no SketchUp foram determinantes para tornar os estudos volumétricos e a construção do partido arquitetônico atividades lúdicas e enriquecedoras. A internet facilitou acesso à informação sobre as várias técnicas e materiais, os arquitetos e suas obras. É importante destacar que as pesquisas de referências foram fundamentais no processo de ensino e aprendizagem e durante os seminários realizados fomentaram discussões diversificadas que puderam ser compartilhadas como assessorias coletivas. Dessa forma, valorizou-se a organização sobre as informações adquiridas na projetação.

A junção de turmas em estágio diferente no curso (alunos ingressantes e alunos de segundo ano) mostrou ser uma fonte de enriquecimento no aprendizado: por um lado, os alunos mais antigos estimulavam os mais novos a adquirir conhecimentos e habilidades na projetação e representação. Por outro lado, os mais novos estimulavam os mais antigos a sistematizar seu conhecimento para explicar suas atividades e responder perguntas, o que favorecia a consolidação de sua aprendizagem.

O Ateliê Digital integrado demandou mais trabalho por parte dos docentes, que precisaram acompanhar e avaliar alunos em estágios diferentes, respeitando e estimulando o crescimento de cada um segundo seu nível de amadurecimento, além de prepararem e ministrarem dois cursos distintos simultaneamente. Ficou demonstrado a necessidade do planejamento cuidadoso e detalhado de todas as atividades, de modo a preservar a necessidade de aprendizagem de cada grupo, cuidando da oferta de atividades coletivas ou individualizadas para cada um deles, de modo a não sobrecarregar os alunos mais novos nem desestimular os mais avançados.

Ao final das atividades do Ateliê Digital Integrado os professores perceberam o amadurecimento e a evolução dos alunos, tanto da turma Ateliê II, quanto da turma Ateliê I. Eles desenvolveram autonomia e curiosidade sobre a arquitetura e novas tecnologias de projeto e representação. Ainda, com o objetivo de compreender, segundo a perspectiva dos alunos, questões sobre o processo e o aprendizado, foi realizado com os alunos, monitores e professores do Ateliê Digital Integrado, um debate sobre a metodologia utilizada e os resultados alcançados. Numa abordagem qualitativa, a maioria dos alunos considerou como positiva a metodologia adotada e sentiram-se satisfeitos com os resultados alcançados. Alguns alunos lamentaram a ausência da criação de maquetes físicas, de exercícios que envolvessem medições e desenho (cadastro) e da aplicação de projetos menores, envolvendo reformas. Não houve reclamações sobre dificuldades encontradas no manuseio dos softwares nem sobre possíveis limitações das ferramentas empregadas quanto à criatividade.

Concluindo, a utilização do computador, especialmente nas turmas iniciais, quando os alunos estão descobrindo o universo arquitetônico, pode potencializar o processo de ensino-aprendizagem, dinamizando as atividades e trazendo novas perspectivas sobre os resultados. O uso da tecnologia incorporado à projetação e as diferentes abordagens nas atividades foram determinantes na consolidação da metodologia ativa utilizada. 


\section{REFERÊNCIAS}

ANDRADE, M. L. V. X. Computação gráfica tridimensional e ensino de arquitetura: uma experiência pedagógica. CONGRESSO INTERNACIONAL DE ENGENHARIA GRÁFICA NAS ARTES E NO DESENHO, 7., 2007, Curitiba. Anais [...] Curitiba: UFPR, 2007. 1 CD-ROM.

BARISON, M. B. Introdução de modelagem da informação da construção (BIM) no currículo: uma contribuição para a formação do projetista. 2015. 387 p. Tese (Doutorado em Engenharia de Construção Civil) - Escola Politécnica da Universidade de São Paulo, São Paulo, 2015

BATISTELLO, P.; BALZAN, K. L.; PEREIRA, A. T. C. Integração no ensino de arquitetura e urbanismo: experiências com ateliês verticais. Revista Projetar. Natal, v. 1; n. 3; p. 47-59; 2016. Disponível em: https://periodicos.ufrn.br/revprojetar/ article/view/16612. Acesso em: 9 jan. 2020.

CAMARGO, F.; DAROS, T. A sala de aula inovadora: estratégias pedagógicas para fomentar o aprendizado ativo. Porto Alegre: Penso, 2018.

BROADBENT, G. Diseño arquitectónico. Arquitectura y Ciencias Humanas. Barcelona: Gustavo Gili, 1973.

EDWARDS, B. Desenhando com o lado direito do cérebro. Rio de Janeiro: Ediouro, 2005.

FLORIO, W. Contribuições do building information modeling no processo de projeto em arquitetura. ENCONTRO DE TECNOLOGIA DA INFORMAÇÃO E COMUNICAÇÃO NA CONSTRUÇÃO CIVIL, 3., 2007, Porto Alegre. Anais [...]. Porto Alegre: ANTAC, 2007. 1 CD-ROM.

Notas sobre pensamento e cognição em projetos paramétricos ENCONTRO DA ASSOCIAÇÃO NACIONAL DE PESQUISA E PÓS-GRADUAÇÃO EM ARQUITETURA E URBANISMO, 2. 2012, Natal. Anais [...]. Natal: ANPARQ, 2012. 1 CD-ROM.

GEBRAN, M. P. Tecnologias educacionais. Curitiba: IESDE Brasil, 2009.

KIM, J. Use of BIM for effective visualization teaching approach in construction education. Journal of professional issues in engineering education and practice. ASCE, v. 138, n. 3, p. 214-223, 2012. Disponível em: http://www.ascelibrary.org. Acesso em: 10 mar. 2013.
KOWALTOWSKI, D. et al. Reflexão sobre metodologias de projeto arquitetônico. Ambiente Construído, v. 6, n. 2, Porto Alegre, 2006. p. 7-19. Disponível em: http://seer.ufrgs.br. Acesso em: 15 dez. 2016.

LAWSON, B. CAD na arquitetura: a história até agora. Revista Graf\&Tec, n. 6, p. 31-58, 1999

Como arquitetos e designers pensam. Tradução de Maria Beatriz Medina. São Paulo: Oficina de Textos, 2011.

MACIEL, S. D. Ensino de projeto em ambiente digital: aspectos pedagógicos, tecnológicos e cognitivos. 2019. 346 f. Tese (Doutorado em Arquitetura e Urbanismo) - Faculdade de Arquitetura, Universidade Federal da Bahia, Salvador, 2019.

MACIEL, S. D.; AMORIM, A. L.; CHECCUC$\mathrm{Cl}$, E. S. Ensino de projeto de arquitetura em ambiente digital: uma experiência na Faculdade de Arquitetura da Universidade Federal da Bahia. Gestão e Tecnologia de Projetos, São Carlos, v. 13, n. 1 p. 21-38, 2018. http://dx.doi.org/10.11606/ gtp.v13i1.133839

MALARD, M. L. Alguns problemas de projeto ou de ensino de arquitetura. In: LARA, F.; MARQUES, S. (org.). Cinco textos sobre arquitetura. Belo Horizonte: UFMG, 2005. p. 80-114.

O futuro do projeto em arquitetura e urbanismo: ensino e pesquisa. In: CAMPO-MORI, M. (org.) Aprender fazendo: ensaios sobre o ensino de projetos. Belo Horizonte: Escola de Arquitetura da UFMG, 2018.

MAHFUZ, E. C. Ensaio sobre a razão compositiva. Viçosa: UFV; Belo Horizonte: AP Cultural, 1995.

Reflexões sobre a con-

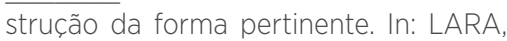
F.; MARQUES, S. (org.). Desafios da pesquisa e do ensino de projeto. Rio de janeiro: Editora Virtual Científica, 2003.

MITCHELL, W. J. A lógica da arquitetura. Tradução de Gabriela Celani. Campinas: Unicamp, 2010

MORAN, J. Metodologias ativas para uma aprendizagem mais profunda. Disponivel em: http://www2.eca.usp.br/ moran/wp-content/uploads/2013/12/ metodologias_moran1.pdf. Acesso em: 6 jan. 2020 
NARDELLI, E. S. Arquitetura e projeto na era digital. Arquitetura Revista, Porto Alegre, v. 3, n. 1, p. 28-36, 2007. Disponível em: https://goo.gl/TdKmDM. Acesso em: 9 jan. 2018.

NEVES, L. P. Adoção do partido na arquitetura. Salvador: EDUFBA, 1998.

OXMAN, R. Digital architecture as a challenge for design pedagogy: theory, knowledge, models and medium. Design studies, Amsterdam, v. 9, n. 2, p. 99-120, 2008. Disponível em: https:// goo.gl/ Z6RNPh. Acesso em: 9 jan. 2018.

ROWE, P. G. Design thinking. Massachusetts: MIT Press, 1991.

$\mathrm{SCHON}, \mathrm{D}$. A. Educando o profissional reflexivo: um novo design para o ensino e a aprendizagem. Tradução de Roberto Cataldo Costa. Porto Alegre: Artmed, 2000.

SILVA, E. Uma introdução ao projeto arquitetônico. Porto Alegre: UFRGS, 1998.

Novos e velhos conceitos no Ensino de Projeto Arquitetônico. In: LARA, F.; MARQUES, S. (org.). Desafios da pesquisa e do ensino de projeto. Rio de janeiro: Editora Virtual Científica, 2003.

VOORDT, T. J. M.; WEGEN, H. B. R. Arquitetura sob o olhar do usuário: programa de necessidades, projeto e avaliação de edificações. Tradução de Maria Beatriz de Medina. São Paulo: Oficina de Textos, 2013.

Sergio Dias Maciel sdmac@terra.com.br

Arivaldo Leão de Amorim alamorim@ufba.br

Érica de Sousa Checcucci erica.checcucci@ufba.br

Kyane Bomfim Santos kyanebomfim@gmail.com 